\title{
Rate of Return to Education and Institu- tional Labour Market Reform in Urban China
}

\author{
Rokhedi Priyo Santoso \\ Universitas Islam Indonesia \\ e-mail:rokhediyahoo.com
}

\begin{abstract}
Modal sumber daya manusia memainkan peran yang penting dalam proses pembangunan. Di antara investasi sumber daya manusia yang paling penting adalah dalam bidang pendidikan. Hasil dari investasi pendidikan akan optimum jika di satu sisi terdapat lingkungan institusi yang berkualitas baik yang akan memberikan insentif berbasis pasar. Di sisi lain, reformasi institusional dalam sektor ketenagakerjaan dapat meningkatkan sistem-sistem insentif untuk meningkatkan produktivitas dan efisiensi. Paper ini mengajukan argumen bahwa reformasi pasar ketenagakerjaan merupakan prasyarat yang sangat diperlukan untuk meningkatkan hasil dari pendidikan.
\end{abstract}

Kata kunci: modal, sumber daya manusia, investasi, reformasi instoitusional.

\section{Introduction}

$\mathrm{H}$ uman capital plays important role in de velopment process. It is also one of distinguished factors explaining across countries economic growth performances. Investment in human capital prevents an economy from fall its marginal productivity of capital. So in the long run, the economy is able to experience sustainable economic growth.

From the various forms of human capital investment, education is the major one. The return on investment in education will be optimum under the good quality of institutional environment that generates the market-based incentives. The institutional reform in labour sector, on the other hand, is able to promote the incentive systems for increasing productivity and efficiency. This paper argues that such labour market reform is a necessary condition for increasing rate of return to education.

This paper is organised as follow: After a brief section about return to education and its international comparison, the paper analyses the significance of the outcomes of labour market reform in favour to increase rate of return to education. For country reference, labour market reform in urban China is viewed as good illustration since its structural transformation from planned economy to the more market-oriented system underlies the success story of its economic performance. Specifically, two main aspects of labour market outcomes are analysed with the comparison between post and pre-reform in China. These two are efficient allo- 
Rate of Return to Education and Institutional Labour Market Reform in...; Rokhedy

cation of labour and performance-based wage determination. A brief analysis on obstacles in increasing return to education is presented in order to identify the significance for further labour market reform.

\section{Literature Review}

\section{Return to Education: an Interna- tional Comparison}

Various studies on return on schooling are developed by econometrics method and cost and benefit analysis. In the econometric, the economists mostly use the model introduced by Mincer (1974) which in simple this model relates earning as function of years of schooling. While with the latter method, the rate of return on investment in education is the rate that equalizes the internal rate of benefit with its cost.

Psacharopouos through extensive studies within period 1974 until 2002 conducted international comparison on return to education which yielded three main conclusions. The first, the decreasing pattern of the return to education with the years of schooling. Compared to the other level of schooling, investment in primary education yields the highest return. Secondly, the developing countries tend to have higher rates of return to education than those in developed countries. It is associated with the diminishing return from expenditure in education since the enrolment in advanced nations is higher than developing ones. Based on the level of per capita income, the average rate of return to secondary education in low income countries is 15.2 per cent in early 1990s. While for the lower middle income and high-income countries are 13.4 and 10.3 per cent, respectively. Meanwhile the world average is 13.5 per cent. Third finding is that the social rate of return is lower than the private return. It is because the cost of education is mostly financed by the state especially for primary and secondary level (Thirlwall 2006).

\section{Return to Education and Institu- tional Labour Market Reform}

The rate of return on education finely represents the incentive for productivity and efficiency allocation of human capital formation. Institutional environment which generate such those systems potentially raises the productivity and efficient allocation labour. Conversely, labour arrangements results in disincentive system for higher productivity and creation of inefficient labour allocation.

Thus, in the context of return to education investment, the successful institutional labour market reform is its ability to increase return to education. There was consistency between the increasing in the rate of return with the rising competitive labour market in China during 1998 - 2002. It is because during the planned economy, the return in undervalued while introduction of market system is expected to revealed the higher return (Appleton, et al 2005).

Labour market reform has significant effect on rising rate of return to education in two ways. The first, the labour market system generates for labour mobility. Secondly, it also guarantees the productivity-wage determination. These two, in turn, create an increase in productivity and efficiency.

\section{1) Labour Mobility}

Labour market system emphasizes the importance of labour mobility since it generates efficient allocation of human resources. The labour mobility enables the economy to reach the efficient technical proportion of capital labour ratio. There are not waste resources under labour mobility. Such those efficient labour allocations will guar- 
antee that the high stock of human capital will promote higher productivity which in turn generate higher return to education.

Introducing labour market reform in urban China has given more flexibility for employers to recruit the most suitable staffs and for the workers to choose the most preferred jobs. In 1983, the government implemented labour contract system in order to reform the old tenure employment system. Two years later, the workers under contract were accounted for 3.7 per cent of total employment and in 1995 it has reached 39.0 per cent of the total employment. This new system relatively succeeded to generate labour mobility in China.

The labour mobility was also accelerated by the rapid growing of urban economy which increased the demand for rural labour. Even though government actually never released the restriction but the control over rural-urban migration loosened. In late 1980s the immigrants accounted for 25 million migrants and increased to 80 million in 1995. This dramatic increase in migration has moderated increase in wages of workers having similar job with the migrants. The most affected worker groups were mostly non-skilled labour who worked in retail and service sectors.

Compared to the past experience under labour market arrangement, China had much lower return to education. Using the data sample from city Nanjing, it was less than 3.7 per cent compared with 14.4 per cent average of developing countries (Byron 1995). This number was also less than those in developed countries. Another year of schooling in China only generated 1.2 per cent increase in earning which is lower than 5- 7 per cent in US and UK in 1981. While compared to Asia, a year increase of schooling was able to raise 11.2 per cent in their earnings (Meng 2000). Other studies con- ducted by J. Knight and L. Song using 3600 sample in urban China, furthermore indicates that return in education in urban China was very low. It was only around 1 per cent (Liu 1988)

The labour arrangements had depressed the low rate of return since the arrangement highly restricted the mobility of workers either by assigned job allocation or restriction in rural-urban migration. Through the assigned job allocation, the government set the employment quota to each province and region. Individual was not allowed to seek the job by themselves since the state guaranteed a job and tenure employment for each of individual. Once they had participated in a certain job, they were restricted to change their employment except for reasonable reason admitted by the government. Employers did not have free authority to recruit their employees. Another limitation on labour mobility was highly restriction in rural-urban migration. Not only did migrated between rural-urban, but there was also limitation in mobility amongst firms. This highly restrictive migration has caused the serious economic problems like hidden unemployment in rural area as well as inefficiency and low productivity in urban area.

All of those restrictions created inefficiency in labour allocation and hidden unemployment which are obstacle for reaching higher productivity. Those inefficiencies were characterized by the existence of shirking problem, mismatch between allocation and firms need, and overstaffed.

\section{2) Performance-Based Wage Determination}

Labour market driven guarantees the level of wage of labour equals to their value of productivity. Theoretically, the wage rate equals to it value of marginal product of 
Rate of Return to Education and Institutional Labour Market Reform in...; Rokhedy

labour. Through investment in education, the labour expects for increasing their marginal productivity which in turn raise their wage and income level. Increasing this earning means the increase in the return on human investment.

Under the labour market reform, the government established wage floating scheme. The total wage bill quota was no longer as a function of number of job allocation but correlated with its profitability. Even though the wages were not fully based on productivity, but this new system has increased the wage slightly. Another important reform is not only changing wage system, but the rewards system was also included non-wage like bonus. The change in the composition of wage system from fixed wage determination to floating wage scheme has generated increase in rate of return to education until 5 percentages points in Guangdong (Liu 1998).

On the other hand, increasing number of non-state enterprises especially foreign investors have offered competitive wages for skilled-workers. By the contract system, many state enterprise workers moved to the foreign private enterprises. In the long run, this condition forced the state enterprises to offer the comparable wage rate in order to maintain their employees not to leave their jobs.

All those conditions were contradictory with the labour condition under the centralized planning. In this period, wages were set by the government where every employer did not have power to determine wage rate. The rates were based on specific grade system in which the personal criteria such as seniority and education level were more dominant rather than productivity. For the employee's perspective, the wage system also paid no attention to the difference in individual performance. Moreover, in period of economic downturn, the incentives systems were abolished. On the other hand, the government who was authorized in wage setting hardly increased the wage rate for long period of time.

The economic implication of the fixed wage determination is that the wage was no longer representing the value of its marginal product. So the existing wage system is unable to potential productivity of the schooling or experience. Again such mechanism failed to create an incentive for individual to work efficiently.

\section{Result and Discussion}

The urban labour market reform slowly progressed by the late 1980's. The rate of return on education in early period of labour reform was still considerably low than other country. Investment return in urban area was still 3-6 per cent. It is considerably lower than average of developing countries (Liu 1998 and Meng 2000). After this period, the return to education increased to 5.6 per cent in 1998 and 6.7 per cent in 1999. In 2002, it slightly increased to 7.5 per cent(Appleton et al 2005). This number shows that the labour market reform in urban China yielded a moderate increase in investment return on education.

Some factors are identified as cause of why return on schooling in urban China is not as high as other developing countries. One of the most important is the ownership structure of state owned enterprises which hinder further labour reforms. There are separated functions in terms of risk bearing by the state and decision making by the manager. While financial risks are bear by the government, the manager tends to maximize the benefit for employees rather than maximize profit. Ironically, the wage determination in state and collective enterprises still 
UNISIA, Vol. XXXII No. 71 Juni 2009

depends on profitability rather than productivity. This system is very contrast with what the private sector which is heavily productivity-based reward system. Another broader factor is that labour market reform is politically sensitive since socialist ideology entails public ownership. This ownership structure is associated with tenure employment which prevents the enterprise operate in efficient manner.

\section{Conclusion}

Under labour arrangements, the existence of immobility human resources and disincentive wage setting failed to promote productivity and efficiency. In turn, all these outcomes lowered the level of return to investment in human capital in China. Introducing the institutional labour market reforms had facilitated the significant increase in rate of return to education in urban China. The labour market reform was successfully created an incentive system for improvement in labour productivity and efficiency in labour allocation which underlies the moderate increase in rate of return on investment in education. Further labour market reform especially in the ownership structure of state owned enterprises is expected to boost the investment return to education in urban China which in turn promotes higher level investment in human capital. At last, the accumulation in human capital enables the economy to experience the sustainable economic growth.

\section{Reference}

Byron, R.P. and Manaloto, E.Q., 1990, 'Return to Education in China', Economic Development and Cultural Change, 38: 783 - 96
James J. Heckman, 2002. China's Investment in Human Capital, National Bureau of Economic Research Working Paper 9296

Junsen Zhang, Yaohui Zhao, Albert Park, Xiaoqing Song, 2005, 'Economic Returns to Schooling in Urban China', Journal of Comparative Economics, 33: 730-752

Meng, X, 2000. Labour market reform in China, Cambridge University Press

Rodrik, D. (ed), 2003, In search of prosperity: analytical narratives on economic growth, Princeton University Press

Qiang Li, Alan de Brauw, Scott Rozelle, and Linxiu Zhang, 2005, 'Labour Market Emergence and Returns to Education in Rural China', Review of Agricultural Economics, 27 (3): 418 - 424

Simon Appleton, Lina Song, Qingjie Xia, 2005, 'Has China Crossed the River? the evolution of wage structure in urban China during reform and retrenchment', Journal of Comparative Economics, 33: 644 - 663

Thirlwall, A.P., 2006. Growth and Development With Special Reference to Developing Economies, Palgrave Macmillan

Liu, Z., 1998, ‘Earnings, Education, and Economic Reforms in Urban China', Economic Development and Cultural Change, 46 (4): 697 - 725, The University of Chicago 